\title{
Risk for gastric cancer in people with CagA positive or CagA negative Helicobacter pylori infection
}

\author{
J Parsonnet, G D Friedman, N Orentreich, H Vogelman
}

\begin{abstract}
Background and aims-It is not known why some people with Helicobacter pylori infection develop gastric cancer whereas others do not. Whether the CagA phenotype of $\boldsymbol{H}$ pylori infection affected risk for cancer independently of other posited risk factors was evaluated.

Subjects-242 persons who participated in a previous nested case-control study of gastric cancer. 179 (90 cases and 89 controls) were infected with $H$ pylori as determined by enzyme linked immunosorbent assay (ELISA) in serum and 63 (13 cases and 50 controls) were uninfected.

Methods-Serum samples from cases and controls, obtained a mean of $14 \cdot 2$ years before diagnosis of cancer in the cases, were tested by ELISA for IgG antibodies against the CagA gene product of $H$ pylori. They had previously been tested for pepsinogen I. Using logistic regression analysis, risk for cancer was compared among infected persons with $\mathrm{CagA}$ antibodies, infected persons without CagA antibodies,
\end{abstract} and uninfected persons.

Results-Subjects infected with $H$ pylori who had CagA antibodies were 5.8-fold more likely than uninfected subjects to develop gastric cancer (95\% confidence interval $(95 \% \mathrm{CI})=2 \cdot 6-13 \cdot 0)$. This was true for both intestinal (odds ratio (OR) $5 \cdot 1$, $95 \% \mathrm{CI}=2 \cdot 1-12 \cdot 2)$ and diffuse type (OR $10 \cdot 1,95 \% \mathrm{CI}=2 \cdot 2-47 \cdot 4)$ cancers. By contrast, $H$ pylori infected subjects without CagA antibodies were only slightly, and not significantly, at increased risk for cancer (OR $2 \cdot 2,95 \% \mathrm{CI}=0 \cdot 9-5 \cdot 4)$ and any possible association was restricted to diffuse type carcinoma (OR 9.0, 95\% CI=1·2-65.8). Pepsinogen $1<50 \mathrm{ng} / \mathrm{ml}$ significantly increased risk for both cancer types in $H$ pylori infected persons and lessened the magnitude of association between CagA and cancer. Educational attainment, cigarette smoking, and ABO blood group were not associated with malignancy.

Conclusions-When compared with uninfected subjects, persons infected with CagA positive $H$ pylori are at considerably increased risk of gastric cancer. CagA negative $H$ pylori are less strongly linked to malignancy and may only be associated with diffuse type disease.

(Gut 1997; 40: 297-301)
Keywords: Helicobacter pylori, gastric neoplasm, CagA, pepsinogen, $\mathrm{ABO}$ blood group, cigarette smoking.

Infection with Helicobacter pylori has been identified as a risk factor for gastric adenocarcinoma of the antrum and corpus. ${ }^{12}$ Epidemiological studies indicate that infection increases risk for both intestinal and diffuse histological types of cancer between threefold and sixfold. As a consequence, the International Agency for Research on Cancer recently termed $H$ pylori a group I carcinogen, a definite cause of cancer in humans. ${ }^{3}$ Yet, because only a minority of subjects infected with $H$ pylori will develop cancer, other factors must be important in determining cancer occurrence. Among non-infectious risk factors, diet, cigarette smoking, and socioeconomic status have been of most enduring interest. ${ }^{4-7}$ Genetic characteristics of the host, such as ABO blood type, may also influence outcome of infection. Blood group $\mathrm{O}$ is postulated to contribute to $H$ pylori adherence and to $H$ pylori related duodenal ulceration. ${ }^{8}{ }^{9}$ Blood group $\mathrm{A}$, on the other hand, has been associated with the diffuse type of gastric cancer. ${ }^{7}$

Helicobacter pylori is not a clonal organism and exhibits great genetic diversity. ${ }^{10-13}$ At the phenotypic level, strains can be characterised into two types: those that contain a gene associated with cytotoxin expression, the socalled CagA gene, and those that do not. ${ }^{14}$ Expression of the CagA protein can be sensitively and specifically diagnosed by detecting antibodies to it. CagA positive $H$ pylori, which comprise some $50 \%-60 \%$ of United States isolates, cause more extensive inflammation of the gastric mucosa than CagA negative strains. ${ }^{16-20}$ CagA positive infections are also more likely to progress to atrophic gastritis than CagA negative infections. ${ }^{21}$ Furthermore, a nested case-control study among JapaneseAmerican men suggested that CagA antibodies are more common in infected persons with gastric malignancy than in infected persons without such malignancy. ${ }^{22}$ Whereas this finding was not statistically significant, the twofold increase in CagA positive $H$ pylori among intestinal type cancers appeared unlikely to be due to chance alone.

In 1990, we conducted a nested case-control study of $H$ pylori and gastric cancer among men and women in a northern California healthcare programme. ${ }^{1}$ We found $H$ pylori antibodies to 
be $3 \cdot 6$-fold more common in persons who later developed gastric cancer than in matched controls. Subsequently, we identified a low pepsinogen 1 level $(<50 \mathrm{ng} / \mathrm{ml})$ also to be associated with development of cancer, although only in people with $H$ pylori infection. ${ }^{23}$ Because it remains unknown why some people with $H$ pylori infection develop cancer whereas others do not, we decided to assess risk factors for cancer among $H$ pylori infected subjects only. Factors of interest include antibodies to the CagA protein, pepsinogen I concentration (an indicator of concurrent atrophic gastritis), $\mathrm{ABO}$ blood group type, and level of education (a surrogate for socioeconomic status). We also compared risk for gastric cancer among three groups: persons with CagA positive $H$ pylori infection, those with CagA negative $H$ pylor infection, and those without $H$ pylori.

\section{Methods}

Subjects had been previously identified for a nested case-control study of $H$ pylori and gastric cancer. ${ }^{1}$ Cases of gastric cancer and controls were selected from among 128992 subjects who had provided serum as part of a multiphasic health evaluation at Kaiser Permanente Medical Care Program between 1964 and 1969. Histological sections and records from cohort members who developed gastric cancer subsequent to their multiphasic examination (cases) were reviewed and tumours were classified by histological type and site within the stomach as previously described. ${ }^{1}$ Each confirmed case was then matched by five year birth cohort, sex, race, site, and date of serum collection (same month and year) to one cohort member (control) who had not developed cancer in the time up to and including the year of diagnosis. Serum samples were tested for $H$ pylori antibodies as previously reported (Table I). ${ }^{123}$ Subjects with antibody titres higher than the mean of 15 low positive standards were considered to be infected with $H$ pylori. From 107 cases of intestinal or diffuse type cancer of the corpus or antrum, 103 serum samples remained available for CagA antibody testing; 90 of these samples had been positive for $H$ pylori antibodies by enzyme linked immunosorbent assay (ELISA). Controls included subjects previously matched to adenocarcinomas of the stomach and gastro-oesophageal junction and to gastric lymphomas. Among 147 control serum samples, eight were no longer available for testing. Of the remaining 139, 89 were from $H$ pylori antibody positive subjects.

Serum samples from all subjects ( $H$ pylori positive and negative) were tested by ELISA

TABLE I Helicobacter pylori and CagA serology results for cancer cases and controls

\begin{tabular}{|c|c|c|c|c|c|}
\hline & \multirow[b]{2}{*}{$n$} & \multicolumn{2}{|c|}{ H pylori seropositive } & \multicolumn{2}{|c|}{ H pylori seronegative } \\
\hline & & $n(\%)$ & $n$ CagA+ (\%) & $n(\%)$ & $n \operatorname{Cag} A+(\%)^{*}$ \\
\hline $\begin{array}{l}\text { Cases } \\
\text { Intestinal } \\
\text { Diffuse }\end{array}$ & $\begin{array}{r}103 \\
77 \\
26\end{array}$ & $\begin{array}{l}90(87 \cdot 4) \\
67(87 \cdot 0) \\
23(88 \cdot 5)\end{array}$ & $\begin{array}{l}70(77 \cdot 8) \\
54(80 \cdot 6) \\
16(69 \cdot 6)\end{array}$ & $\begin{array}{c}13(12 \cdot 6) \\
10(13.0) \\
3(1.5)\end{array}$ & $\begin{array}{l}1(7 \cdot 7) \\
1(10) \\
0(0)\end{array}$ \\
\hline Controls & 139 & $89(64 \cdot 0)$ & $48(53.9)$ & $50(36 \cdot 0)$ & $4(8 \cdot 0)$ \\
\hline
\end{tabular}

$\star$ People with negative $H$ pylori serology and positive CagA serology were excluded from analysis. for antibodies to the $H$ pylori CagA protein (OraVax, Inc, Cambridge, MS, USA) as previously described. ${ }^{172}$ This assay, which uses as antigen the orv 220 fragment of CagA, is highly sensitive and specific for infection with CagA positive strains. Briefly, microtitre wells were coated with $1 \mu \mathrm{g}$ orv 220 antigen in carbonate-bicarbonate buffer. Test serum samples at a dilution of $1: 100$ were incubated $\underset{\vec{S}}{\stackrel{\vec{S}}{+}}$ in the wells at $37^{\circ} \mathrm{C}$ for one hour. The second $\mathrm{O}$ antibody, a goat antihuman IgG alkaline phos- 흘 phatase conjugate, was then added at a dilution $\frac{\bar{\omega}}{7}$ of $1: 1000$ at $37^{\circ} \mathrm{C}$ for one hour. After incu- $\stackrel{\mathbb{D}}{\Omega}$ bation with phosphatase substrate, the optical density was read at $405 \mathrm{~nm}$. All samples were $\vec{\circ}$ run in triplicate. A titre was considered positive if the optical density exceeded the mean plus $\vec{\omega}$ 3 SD of serum samples from 12 subjects without CagA positive infections. Using this cutoff point, we evaluated serum samples from to 12 persons infected with CagA gene positive $H \dot{\omega}$ pylori, nine persons infected with CagA gene negative $H$ pylori, and five persons without $H_{0}$ pylori by histology, culture, or rapid urease test. In this group, the assay was $100 \%$ sensitive and $\vec{z}$ specific for CagA infection status.

In a previous study, serum samples had been $\frac{\widehat{S}}{\partial}$ tested for pepsinogen $\mathrm{I}^{23}$; a concentration $<50 \vec{\theta}$ $\mathrm{ng} / \mathrm{ml}$ greatly increased the risk for cancer. This level is now categorised as "low pepsinogen I". Work by other investigators suggests that this low concentration of pepsinogen I detects moderate to severe corpus atrophy with $72 \%$ sensitivity and $85 \%$ specificity. ${ }^{24}{ }^{25}$

We evaluated level of education using three $\stackrel{\varrho}{\Rightarrow}$ categories: less than high school, high school or $\frac{0}{3}$ trade school, and college or higher. We compared A $v$ non-A ABO blood group and $\mathrm{O} v$ 吾 non-O ABO blood groups. Cigarette smoking had been determined by questionnaire when serum was collected. Information was categor- 훅 ised by current smoking status (current smoker, ex-smoker, non-smoker). Among 윽 smokers and ex-smokers, cigarette smoking was further categorised by duration of use $(<10$ 윽 years, 10-20 years, and $>20$ years) and quan- $\frac{D}{O}$ tity of cigarettes smoked daily (<one pack, one to two packs, and >two packs).

Data were analysed with EpiInfo (Centers N for Disease Control, Atlanta, GA, USA) and N Egret (Statistics and Epidemiology Research Corporation, Seattle, WA, USA) programs. For univariate comparisons between cases and $\frac{}{\mathscr{C}}$ controls, we used a $\chi^{2}$ test with Yates's correction, $t$ test, or Wilcoxon rank sum test. To evaluate whether infection with the specific $\stackrel{\vec{P}}{\vec{P}}$

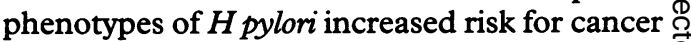
compared with uninfected subjects, we per- $\stackrel{\square}{\square}$ formed logistic regression using the entire population of infected and uninfected subjects. In multivariate analysis, we adjusted for allo variables previously used for matching including age at serum donation, sex, race, and $\stackrel{0}{\supset}$ date of serum donation. Subjects infected with each type of $H$ pylori were omitted from the analysis of infection with the other type. Again, data were adjusted for age, sex, race, and date of serum collection. Interaction was investigated between all variables significant at $\mathrm{p}<0 \cdot 1$. 


\section{Results}

A total of 103 cases (77 intestinal type and 26 diffuse type) and 139 controls were tested for CagA antibodies. At the time that serum was collected, those who later developed diffuse type cancer were younger than both controls and those who developed intestinal type cancer (Table II). Other demographic features were similar among cases and controls. Serum samples had been obtained a mean of 14.2 years before diagnosis of cancer in the cases.

Among subjects without $H$ pylori antibodies, five (one case and four controls) had positive titres for CagA. Because of the ambiguity of these results, these subjects were excluded from further analysis. Among the remainder, $H$ pylori infected subjects with CagA antibodies had a strongly increased risk for gastric cancer compared with uninfected subjects (Table III). This was true for both intestinal and diffuse type cancers. Risk for cancer was modestly but not significantly increased among CagA negative subjects infected with $H$ pylori compared with uninfected subjects (Table III). When stratified by tumour type, however, CagA negative $H$ pylori seemed to be statistically linked to diffuse type disease. The few subjects in this subgroup, however, make the risk estimate imprecise.

TABLE II Demographic features of cases and controls

\begin{tabular}{|c|c|c|c|}
\hline \multirow[b]{2}{*}{ Feature } & \multicolumn{2}{|l|}{ Cancer } & \multirow[b]{2}{*}{$\begin{array}{l}\text { Controls } \\
(n=139)\end{array}$} \\
\hline & $\begin{array}{l}\text { Intestinal } \\
(n=77)\end{array}$ & $\begin{array}{l}\text { Diffuse } \\
(n=26)\end{array}$ & \\
\hline Female (\%) & $29 \cdot 9$ & $39 \cdot 1$ & $24 \cdot 7$ \\
\hline \multicolumn{4}{|l|}{ Race (\%): } \\
\hline White & $65 \cdot 7$ & 73.9 & $73 \cdot 0$ \\
\hline African-American & $32 \cdot 8$ & $17 \cdot 4$ & $27 \cdot 7$ \\
\hline Asian & 1.5 & $8 \cdot 7$ & $2 \cdot 2$ \\
\hline \multicolumn{4}{|l|}{ Level of education $(\%):^{\star}$} \\
\hline Elementary and grade school & $35 \cdot 5$ & $22 \cdot 7$ & $32 \cdot 6$ \\
\hline High school or trade school & $37 \cdot 1$ & $45 \cdot 5$ & $37 \cdot 1$ \\
\hline College education & $27 \cdot 4$ & $26 \cdot 7$ & $25 \cdot 8$ \\
\hline \multicolumn{4}{|l|}{ ABO blood group (\%):† } \\
\hline $\mathrm{O}$ & 43.9 & $43 \cdot 5$ & $50 \cdot 0$ \\
\hline A & $40 \cdot 9$ & 43.5 & $31 \cdot 8$ \\
\hline B & $12 \cdot 1$ & $13 \cdot 0$ & $12 \cdot 5$ \\
\hline AB & $3 \cdot 0$ & 0.0 & $5 \cdot 6$ \\
\hline \multicolumn{4}{|c|}{ Cigarette smoking at time of serum collection $(\%): \ddagger$} \\
\hline Smoker & 33.9 & $37 \cdot 5$ & $29 \cdot 3$ \\
\hline Ex-smoker & $18 \cdot 6$ & $12 \cdot 5$ & $29 \cdot 3$ \\
\hline Non-smoker & $47 \cdot 4$ & $50 \cdot 0$ & $41 \cdot 3$ \\
\hline Mean age when serum was obtained & $56 \cdot 05$ & $50 \cdot 7$ & $56 \cdot 1 \S$ \\
\hline Median $H$ pylori IgG titref & $3 \cdot 1$ & $3 \cdot 1$ & $3 \cdot 5$ \\
\hline Low pepsinogen (\%) III & $45 \cdot 0$ & $40 \cdot 9$ & $15 \cdot 6 \S^{\star \star}$ \\
\hline Mean age diagnosis of cancer & $70 \cdot 1$ & $67 \cdot 4$ & - \\
\hline
\end{tabular}

$\star$ Data missing for five intestinal cases, one diffuse case and five controls.

tData missing for one intestinal case and one control.

$\neq$ Data missing for eight intestinal cases, seven diffuse cases, and 14 controls.

p $<0.05 v$ diffuse cancer cases.

Value is expressed as the ratio of the sample titre to the mean of three low positive standards.

ll Defined as a serum pepsinogen I concentration $<50 \mathrm{ng} / \mathrm{ml}$. Information missing for seven

intestinal cases, one diffuse case, and 12 controls.

${ }_{\star \star} \mathrm{p}<0.05 v$ intestinal cancer cases.
In a separate analysis we evaluated risk factors for cancer among only subjects infected with $H$ pylori. Of the cases with $H$ pylori antibodies, $77 \cdot 8 \%$ also had antibodies to CagA compared wtih $53.9 \%$ of infected controls (odds ratio (OR) 3.3, 95\% confidence interval $(95 \% \mathrm{CI})=1 \cdot 6-6 \cdot 5)$. Seropositivity for CagA was significantly associated with gastric cancer (OR 3.3, 95\% CI=1·6-6.5). Among cases of intestinal type cancer, the OR was 3.8 (95\% $\mathrm{CI}=1 \cdot 7-8 \cdot 4)$ whereas among cases of diffuse cancer the $\mathrm{OR}$ was lower and not significant (OR $2 \cdot 1,95 \%$ CI $=0 \cdot 7-6 \cdot 1$ ).

Of the 179 subjects infected with $H$ pylori, 159 had had serum tested for pepsinogens; of these $50(31.3 \%)$ had pepsinogen I concentrations $<50 \mathrm{ng} / \mathrm{ml}$. Thirty nine $(36.4 \%)$ of 107 subjects with CagA antibodies had low pepsinogen I concentrations at the time the serum was obtained compared with 11 of $52(22 \cdot 4 \%)$ subjects without CagA antibodies $(p=0 \cdot 1)$. When pepsinogen I was added to the multivariate model of CagA, CagA seropositivity remained a significant risk factor for intestinal type cancer, although the magnitude of the association decreased (Table IV). Low pepsinogen I was strongly associated with later development of both intestinal and diffuse type malignancy.

If CagA protein caused cancer uniquely through induction of atrophy, then the association between CagA and cancer should tend to weaken as the interval between serum collection and cancer diagnosis lessened; conversely, the association between low pepsinogen and cancer would be expected to increase. The opposite was observed. In 41 cases with 15 years or more between serum collection and cancer diagnosis, CagA only increased risk for cancer 1.2-fold after adjustment for pepsinogen concentration $(95 \% \quad \mathrm{CI}=0 \cdot 5-3 \cdot 0)$ whereas low pepsinogen I was a strong risk

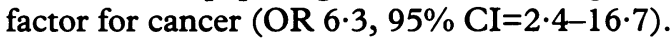
In 41 cases with an interval $<15$ years between serum collection and cancer the OR was 3.8 for CagA (95\% CI $=1 \cdot 3-10 \cdot 5)$ and $4 \cdot 1$ for low pepsinogen $\mathrm{I}(95 \% \mathrm{CI}=1 \cdot 5-10 \cdot 7)$.

In no analysis among $H$ pylori infected cases and controls was the level of educational attainment, cigarette smoking, or ABO blood group significantly associated with development of malignancy (Table V). Because type A blood seemed to be somewhat more common in cases than in controls and because this blood group has been identified as a risk factor only for diffuse cancer, we stratified our analysis by tumour type. The association between type A

TABLE III Risk for stomach cancer in people with CagA positive $\mathrm{H}$ pylori infection and CagA negative $\mathrm{H}$ pylori infection compared with uninfected controls*

\begin{tabular}{|c|c|c|c|c|c|c|}
\hline & \multicolumn{3}{|c|}{ CagA positive v uninfected } & \multicolumn{3}{|c|}{ CagA negative $\mathrm{v}$ uninfected } \\
\hline & $\begin{array}{l}\text { Cases } \\
\text { with } \mathrm{H} \text { pylori } \\
n(\%)\end{array}$ & $\begin{array}{l}\text { Controls } \\
\text { with } \mathrm{H} \text { pylori } \\
n(\%)\end{array}$ & $\begin{array}{l}O R^{*} \\
(95 \% C I)\end{array}$ & $\begin{array}{l}\text { Cases } \\
\text { with } \mathrm{H} \text { pylori } \\
n(\%)\end{array}$ & $\begin{array}{l}\text { Controls } \\
\text { with } \mathrm{H} \text { pylori } \\
n(\%)\end{array}$ & $\begin{array}{l}O R^{*} \\
(95 \% C I)\end{array}$ \\
\hline $\begin{array}{l}\text { All cancers } \\
\text { Intestinal cancer } \\
\text { Diffuse cancer }\end{array}$ & $\begin{array}{l}70 / 82(85 \cdot 4) \\
54 / 63(85 \cdot 7) \\
16 / 19(84 \cdot 2)\end{array}$ & $\begin{array}{l}48 / 94(51 \cdot 1) \\
48 / 94(51 \cdot 1) \\
48 / 94(51 \cdot 1)\end{array}$ & $\begin{array}{r}5 \cdot 8(2 \cdot 6 \text { to } 13 \cdot 0) \\
5 \cdot 1(2 \cdot 1 \text { to } 12 \cdot 1) \\
10 \cdot 1(2 \cdot 7 \text { to } 47.5)\end{array}$ & $\begin{array}{r}20 / 32(62 \cdot 5) \\
13 / 22(59 \cdot 1) \\
7 / 10(70 \cdot 0)\end{array}$ & $\begin{array}{l}41 / 87(47 \cdot 1) \\
41 / 87(47 \cdot 1) \\
41 / 87(47 \cdot 1)\end{array}$ & $\begin{array}{l}2.2(0.9 \text { to } 5.4) \\
1.4(0.5 \text { to } 3.9) \\
9.0(1.2 \text { to } 65.8)\end{array}$ \\
\hline
\end{tabular}

^Analysis adjusted for age, sex, race, and date of serum collection with the exception of the analysis of diffuse cancer in CagA negative $v$ uninfected groups. Because of small numbers, this analysis could not be adjusted by race. 
TABLE IV Risk for gastric cancer in subjects infected with $\mathrm{H}$ pylori associated with CagA antibody and low pepsinogen I concentration $(<50 \mathrm{ng} / \mathrm{ml})$, unadjusted for each other and adjusted for each other ${ }^{\star}$

\begin{tabular}{|c|c|c|c|}
\hline & $\begin{array}{l}\text { Unadjusted OR } \\
\text { (95\% CI) }\end{array}$ & $\begin{array}{l}\text { Adjusted OR } \\
(95 \% C I)\end{array}$ & p Value \\
\hline \multicolumn{4}{|l|}{ Intestinal cancer: } \\
\hline $\begin{array}{l}\text { CagA antibodies } \\
\text { Low pepsinogen I }\end{array}$ & $\begin{array}{l}3 \cdot 1(1 \cdot 4 \text { to } 7 \cdot 1) \\
5 \cdot 2(2 \cdot 2 \text { to } 12 \cdot 0)\end{array}$ & $2 \cdot 6$ t $(1 \cdot 1$ to $6 \cdot 1)$ & $\begin{array}{l}0.03 \\
<0.001\end{array}$ \\
\hline \multicolumn{4}{|l|}{ Diffuse cancer: } \\
\hline $\begin{array}{l}\text { CagA antibodies } \\
\text { Low pepsinogen I }\end{array}$ & $\begin{array}{l}1.7(0.6 \text { to } 5.0) \\
7.0(1.9 \text { to } 25.7)\end{array}$ & $\begin{array}{l}1.3 \ddagger(0.4 \text { to } 4.1) \\
6.7(1.8 \text { to } 25 \cdot 0)\end{array}$ & $\begin{array}{l}0.6 \\
0.005\end{array}$ \\
\hline \multicolumn{4}{|l|}{ All cancers: } \\
\hline $\begin{array}{l}\text { CagA antibodies } \\
\text { Low pepsinogen I }\end{array}$ & $\begin{array}{l}2.6(1.3 \text { to } 5.5) \\
5.5(2.5 \text { to } 12 \cdot 3)\end{array}$ & $\begin{array}{l}2.3(1.0 \text { to } 5.9) s \\
5.1(2.3 \text { to } 11 \cdot 6)\end{array}$ & $\begin{array}{l}0.04 \\
<0.001\end{array}$ \\
\hline
\end{tabular}

^Excludes two intestinal cases, one diffuse case, and 12 controls from whom pepsinogen 1 concentrations were not available. All analyses were adjusted for age, sex, race, and date of serum donation.

tOR for CagA without adjustment for pepsinogen=3.3 (95\% CI 1.4 to $7 \cdot 5)$.

tOR for CagA without adjustment for pepsinogen $=1.8(95 \% \mathrm{CI} 0.6$ to $5 \cdot 4)$.

SOR for CagA without adjustment for pepsinogen $=2 \cdot 8(95 \% \mathrm{CI} 1 \cdot 3$ to $5 \cdot 8)$.

TABLE V Risk for gastric cancer associated with education, ABO blood group, and cigarette smoking among people infected with $\mathrm{H}$ pylori

\begin{tabular}{|c|c|c|c|}
\hline & $\begin{array}{l}\mathrm{H} \text { pylorit/CagA+ } \\
\mathrm{H} \text { pylori+/CagA- } \\
\text { OR }(95 \% \text { CI })\end{array}$ & $\begin{array}{l}\mathrm{H} \text { pylorit/CagA+v } \\
\text { uninfected } \\
\text { OR }(95 \% C I)\end{array}$ & $\begin{array}{l}\mathrm{H} \text { pylori+/CagA- } \mathrm{v} \\
\text { uninfected } \\
\text { OR }(95 \% C I)\end{array}$ \\
\hline \multicolumn{4}{|l|}{ Level of education: } \\
\hline Elementary and grade school & $1 \cdot 0$ & $1 \cdot 0$ & $1 \cdot 0$ \\
\hline High school or trade school & $0.9(0.4$ to 2.0$)$ & $0.7(0.3$ to 1.5$)$ & $1.5(0.5$ to 4.5$)$ \\
\hline College education & $0.9(0.4$ to 2.2$)$ & $0.6(0.3$ to 1.5$)$ & $1.2(0.4$ to 3.9$)$ \\
\hline \multicolumn{4}{|l|}{ Cigarette use: } \\
\hline Non-smoker & $1 \cdot 0$ & $1 \cdot 0$ & $1 \cdot 0$ \\
\hline Ex-smoker & $0.5(0.2$ to 1.2$)$ & $0.7(0.3$ to 1.7$)$ & $0.6(0.2$ to $2 \cdot 1)$ \\
\hline Current smoker & $1 \cdot 1(0.5$ to $2 \cdot 6)$ & $0.9(0.4$ to 2.2$)$ & $1 \cdot 1(0.4$ to 3.2$)$ \\
\hline \multicolumn{4}{|l|}{ ABO Blood group: } \\
\hline Blood group not $\mathrm{A}$ & $1 \cdot 0$ & $1 \cdot 0$ & $1 \cdot 0$ \\
\hline Blood group A & $1.7(0.9$ to 3.3$)$ & $1.3(0.6$ to 2.5$)$ & $1 \cdot 1(0.4$ to $2 \cdot 5)$ \\
\hline
\end{tabular}

*All analyses adjusted for CagA antibody, age, sex, race, and date of serum donation.

blood and cancer was similar in both tumour subgroups (OR for intestinal cancer 1.9, 95\% $\mathrm{CI}=0.9-3.9$; OR for diffuse cancer $1 \cdot 6,95 \%$ CI $0 \cdot 6-4 \cdot 4)$.

\section{Discussion}

Helicobacter pylori infection causes both intestinal and diffuse types of gastric adenocarcinoma. The organism's carcinogenic effects have been imputed to induction of inflammation. Yet not all $H$ pylori strains cause similar inflammatory changes. The phenotype of $H$ pylori that expresses CagA causes higher degrees of acute and chronic inflammation than the CagA negative phenotype, for unknown reasons. ${ }^{16}{ }^{18} 26-28$ Our study suggests that this difference in phenotype impacts the risk for malignancy. Overall, CagA positive strains were three times more likely to lead to cancer than CagA negative strains. This only held true in the subgroup of intestinal type cancers. Moreover, when compared with uninfected subjects, persons infected with CagA negative strains had only a modest but not significant, increase in their risk for cancer. When evaluated by tumour type, however, an interesting pattern was seen. Both phenotypes of $H$ pylori seemed to increase risk for diffuse type cancer but only the CagA phenotype was associated with intestinal type malignancy. This suggests that the mechanisms of carcinogenesis imputed to $\dot{H}$ pylori differ for the two types of cancer. Some likely confounders measured in this study (socioeconomic status (as indicated by level of education), cigarette smoking, and ABO blood group) did not explain these associations.

Among the reasons $H$ pylori strains may show variation in leading to cancer is a differing prediliction to cause atrophic gastritis. Atrophy has been shown to occur more commonly when the infecting strain expresses cytotoxin $\Rightarrow$ than when it does not. ${ }^{29}$ Although cytotoxin $\stackrel{\vec{P}}{+}$ and CagA are not perfectly associated, cytotoxin expression is statistically much more $\frac{\overline{\bar{D}}}{\overline{\mathrm{N}}}$ common when the CagA gene is also present and expressed. ${ }^{30}{ }^{31}$ Moreover, a recent pros- $\stackrel{\mathbb{Q}}{\circ}$ pective study showed more frequent pro- के gression to atrophic gastritis in subjects with $\vec{\circ}$ CagA positive $H$ pylori infection than in CagA negative infected hosts. ${ }^{21}$ CagA positive strains $\vec{\omega}$ may thus set in action the chain of events that results in intestinal type malignancy. Whereas pepsinogen I concentration is an imperfect marker of atrophy, concentrations below $50 \omega$ $\mathrm{ng} / \mathrm{ml}$ have been reported to indicate moderate to severe corpus atrophy. ${ }^{25}$ In this study, nearly 0 one fourth of the excess risk associated with CagA seropositivity could be explained by con- $\bar{z}$ commitant low pepsinogen concentrations. Misclassification of atrophy by use of the $\frac{O}{工}$ pepsinogen assay rather than direct examin- $\vec{\bullet}$ ation of the mucosa would tend to underestimate this effect. The use of serum samples obtained almost 15 years before diagnosis of cancer could also potentially underestimate the true relation between CagA and atrophic gastritis. Development of corpus atrophy $\mathbb{D}$ during the interval years would have been $\overrightarrow{\vec{B}}$ missed. Yet when we stratified our analysis by $\frac{0}{3}$ interval from serum collection to diagnosis of $\bar{F}$ cancer, there were no trends in the associations among CagA, atrophy, and cancer. Thus 0 whereas a proportion of cancer risk associated with CagA positive $H$ pylori seems to be due to its link with atrophic gastritis, our data suggest other carcinogenic effects of CagA positive strains independent of this pathway.

Diffuse type cancers have not been tradition- 글 ally thought to arise after corpus atrophy but $\frac{D}{0}$ to arise de novo from non-atrophic tissue. ${ }^{4} \mathrm{We}$ had little tissue with which to histopatho- o logically differentiate between intestinal and $N$ diffuse cancers. The presence of glandular N forms in tumours, therefore, could have been 0 missed and diffuse type cancer overdiagnosed. Such misclassification would tend to bias the results towards finding associations between $\stackrel{?}{+}$ atrophy and diffuse malignancy where none $\frac{T}{T}$ truly existed. On the other hand, our cases of $\frac{\vec{D}}{\mathbb{D}}$ diffuse cancer were similar demographically to $\frac{?}{\mathbb{Q}}$ diffuse cancers described in other studies. The $\stackrel{\square}{2}$ patients were younger than those with intestinal cancer, more equally distributed 8 between males and females, and had a higher prevalence of type A blood. ${ }^{1}$ We doubt that misclassification can account entirely for the $?$ findings in this study, but the exact association between CagA, pepsinogen, and diffuse malignancy remains open to question.

In the past 10 years, investigators have begun to piece together the many factors that contribute to gastric carcinogenesis. Among those infected with $H$ pylori, two factors 
enhance risk: seropositivity to CagA and low pepsinogen concentration. Preliminary data indicate that the CagA phenotype is not equally common in all populations. ${ }^{32} 33$ Better understanding of the distribution and interactions among these factors may foster development of intervention strategies to prevent this often fatal malignancy.

We thank OraVax for generously donating the orv220 CagA antigen used in this study. We also thank Ms Shufang Yang and Ms Marilyn Replogle for their technical assistance.

This study was supported by a clinical epidemiology fellowship from Merck and the Society for Epidemiologic Research (JP) and by NIH grant R35CA49761 from the National Cancer Institute (GDF)

1 Parsonnet J, Friedman GD, Vandersteen DP, et al. Helicobacter pylori infection and the risk of gastric carcinoma. N Engl f Med 1991; 325: 1127-31.

2 Nomura AMY, Stemmerman GN, Chyou P, Kato I, PerezPerez GI, Blaser MJ. Helicobacter pylori infection and gastric carcinoma in a population of Japanese-Americans in Hawaii. N Engl f Med 1991; 325: 1132-6.

3 IARC Working Group on the Evaluation of Carcinogenic Risks to Humans. Helicobacter pylori. In: Schistosomes, liver flukes, and Helicobacter pylori: views and expert opinions of an IARC Working Group on the Evaluation of Carcinogenic Risks to Humans. Lyon: IARC, 1994: 177-240.

4 Nomura AM, Stemmermann GN, Chyou PH. Gastric cancer among the Japanese in Hawaii. Fpn $\mathcal{f}$ Cancer Res 1995; 86: 916-23.

5 Kneller RW, You WC, Chang YS, et al. Cigarette smoking and other risk factors for progression of precancerous stomach lesions. $\mathcal{F}$ Natl Cancer Inst 1992; 84: 1261-6.

6 Hansson LE, Baron J, Nyren O, Bergstrom R, Wolk A Adami HO. Tobacco, alcohol, and the risk of gastric cancer. A population-based case-control study in Sweden. cancer. A population-based case

7 Howson C, Hiyama T, Wynder E. The decline in gastric cancer: epidemiology of an unplanned triumph. Epidemiol Rev 1986; 8: 1-27.

8 Boren T, Falk P, Roth KA, Larson G, Normack S. Attachment of Helicobacter pylori to human gastric epithelium mediated by blood group antigens. Science 1993; 262: 1892-5.

9 Mentis A, Blackwell CC, Weir DM, Spiliadis C, Dailianas A Skandalis N. ABO blood group, secretor status and
detection of Helicobacter pylori among patients with detection of Helicobacter pylori among patients with gastric

10 Cover TL, Tummuru MK, Cao P, Thompson SA Blaser MJ. Divergence of genetic sequences for the vacuolating cytotoxin among Helicobacter pylori strains. f Biol Chem 1994; 269: 10566-73.

11 TakamiS, Hayashi T, Tonokatsu Y, Shimoyama T, TamuraT. Chromosomal heterogeneity of Helicobacter pylori isolates by pulsed-field gel electrophoresis. Int $f \mathrm{Med}$ Microbiol Virol Parasitol Infect Dis 1993; 280: 102-7.

12 Desai M, Linton D, Owen RJ, Cameron H, Stanley J. Genetic diversity of Helicobacter pylori indexed with respect to clinical symptomatology, using a $16 \mathrm{~S}$ rRNA and a species-specific DNA probe. $\mathcal{F}$ Appl Bacteriol 1993 75: $574-82$.

13 Taylor DE, Eaton M, Chang N, Salama SM. Construction of a Helicobacter pylori genome map and demonstration of diversity at the genome level. $\mathcal{F}$ Bacteriol 1992; 174: 6800-6.

14 Telford JL, Covacci A, Ghiara P, Montecucco C, Rappuoli R. Unravelling the pathogenic role of Helicobacter pylori in peptic ulcer: potential new therapies and vaccines. Trends Biotechnol 1994; 12: 420-6.

15 Xiang Z, Censini S, Bayeli PF, et al. Analysis of expression of CagA and VacA virulence factors in 43 strains of Helicobacter pylori reveals that clinical isolates can be divided into two major types and that $\mathrm{CagA}$ is not necessary for expression of the vacuolating cytotoxin. Infect Immun 1995; 63: 94-8.

16 Crabtree JE, Covacci A, Farmery SM, et al. Helicobacter pylori induced interleukin-8 expression in gastric epithelial cells is associated with CagA positive phenotype. thelial cells is associated with

17 Cover TL, Glupczynski Y, Lage AP, et al. Serologic detection of infection with cagA + Helicobacter pylori strains. f Clin Microbiol 1995; 33: 1496-500.

18 Crabtree JE, Taylor JD, Wyatt JI, et al. Mucosal IgA recognition of Helicobacter pylori $120 \mathrm{kDa}$ protein, peptic ulceration, and gastric pathology. Lancet 1991; 338: $332-5$.

19 Peek RM, Miller GG, Tham KT, et al. Heightened inflammatory response and cytokine expression in vivo to cag A+ Helicobacter pylori strains. Lab Invest 1995; 73: 760-70.

20 Blaser MJ. Intrastrain differences in Helicobacter pylori: a key question in mucosal damage? Ann Med 1995; 27: 559-63.

21 Kuipers EJ, Perez-Perez GI, Meuwissen SG, Blaser MJ. Helicobacter pylori and atrophic gastritis: importance of the cagA status. F Natl Cancer Inst 1995; 87: 1777-80.

22 Blaser MJ, Perez-Perez GI, Kleanthous $\mathrm{H}$, et al. Infection with Helicobacter pylori strains possessing cagA is associated with an increased risk of developing adenocarcinoma of the stomach. Cancer Res 1995; 55: 2111-5.

23 Parsonnet J, Samloff IM, Nelson LM, Orentreich N, Vogelman JH, Friedman GD. Helicobacter pylori, pepsinogen and risk for gastric adenocarcinoma. Cancer Epidemiol Biomarkers Prev 1993; 2: 1-7

24 Borch K, Axelsson K, Halgreen H, Damkjaer Nielsen MD, Ledin T, Szesci PB. The ratio of pepsinogen A to pepsinogen C: a sensitive test for atrophic gastritis. Scand $\mathcal{f}$ Gastroenterol 1989; 24: 870-6.

25 Kekki M, Samloff IM, Varis K, Ihamaki T. Serum pepsinogen $I$ and serum gastrin in the screening of severe atrophic gastritis. Scand $¥$ Gastroenterol Suppl 1991; 186: atrophic

26 Huang J, O'Toole PW, Doig P, Trust TJ. Stimulation of interleukin-8 production in epithelial cell lines by Helicobacter pylori. Infect Immun 1995; 63: 1732-8

27 Sharma SA, Tummuru MK, Miller GG, Blaser MJ. Interleukin-8 response of gastric epithelial cell lines to Helicobacter pylori stimulation in vitro. Infect Immun 1995; 63: 1681-7.

28 Blaser MJ. Helicobacter pylori phenotypes associated with peptic ulceration. Scand $\mathcal{F}$ Gastroenterol Suppl 1994; 205: $1-5$

29 Fox JG, Correa P, Taylor NS, et al. High prevalence and persistence of cytotoxin-positive Helicobacter pylori strains in a population with high prevalence of atrophic gastritis. Am f Gastroenterol 1992; 87: 1554-60.

30 Atherton JC, Cao P, Peek RM, Tummuru MK, Blaser MJ, Cover TL. Mosaicism in vacuolating cytotoxin alleles of Helicobacter pylori. Association of specific vacA types with cytotoxin production and peptic ulceration. $\mathcal{F}$ Biol Chem 1995; 270: 17771-7.

31 Xiang Z, Censini S, Bayeli PF, et al. Analysis of expression of CagA and VacA virulence factors in 43 strains of Helicobacter pylori reveals that clinical isolates can be divided into two major types and that CagA is not divided into two major types and that CagA is not necessary for expression of
Infect Immun 1995; 63: 94-8.

32 Fauconnier A, Burette A, Goutier S, Butzler JP, Bollen A, Glupczynski Y. Frequency of cagA in Helicobacter pylori strains isolated from Belgian and Moroccan patients [abstract]. Gut 1995; 37: A69.

33 Parsonnet J, Replogle ML, Yang S, Hiatt RA. Prevalence of the type $1 \mathrm{H}$. pylori phenotype differs among ethnic/racial groups in the San Francisco Bay area. F Infect Dis (in groups
press). 